Global Conferences Series:

Social Sciences, Education and Humanities (GCSSSEH), Volume 2, 2019

The $2^{\text {nd }}$ International Conference on Sustainable Development \& Multi-Ethnic Society

DOI: https://doi.org/10.32698/GCS.0169

\title{
The Potentials of Using Digital Primary Sources in History Classroom
}

\author{
Wong Lee King ${ }^{1}$, Mohd Mahzan Awang ${ }^{2}$, Abdul Razaq Ahmad ${ }^{3}$ \& Shakila Che \\ Dahalan $^{4}$ \\ ${ }^{1}$ Faculty of Education UKM, MALAYSIA \\ E-mail: lausdeo93@hotmail.com
}

\begin{abstract}
The latest approach to History Education requires student not to be a passive recipient of encyclopaedic knowledge but as empowered individual that plays an active role in the knowledge generation process. This can be achieved by teaching students how to generate historical knowledge through historical sources. Therefore, digital primary sources (DPS) that refer to primary sources that are in electronic format are very important in History Education. DPS encourage students to relate it in a personal way to past events and promote a better and deeper understanding of past events. However, DPS is underutilized in this digital age, it has not yet been fully accessed and used in a meaningful way. Therefore, this paper presents the definition of DPS and the importance of using DPS in history learning process. Our purpose of this paper is to present a clear review of literature concerning the potentials of using DPS in fostering students' historical thinking skills, fostering students' historical inquiry, encouraging students to view a historical event in a multi perspective way, helping students to gain a deeper understanding of a past event and motivating students to learn history. We further provide suggestions of the implementation and alteration of DPS platforms for various authorities, as well as how educators can use and take advantage of DPS in history teaching and learning process.
\end{abstract}

Keywords: Digitized Primary Sources (DPS), Historical Thinking Skills, Historical Inquiry, History Education

\section{Background}

This article describes the potentials of using digital primary sources in history classroom. Due to previous literature reviews and researches, we believe hands-on access to the digital primary sources had a profound effect on students. Students not only feel comfortable working with different types of information sources, but they also gain valuable experience from interacting with digital primary sources. Therefore, we will discuss how digital primary sources foster students' historical thinking skill, historical inquiry, encouraging students to view a historical event from multi perspective, help students to gain a deeper understanding and motivate students to learn history. Besides that, the implementation and alteration of digital primary sources for various authorities will be discussed at the end of this article.

\section{Introduction}

Since 2013, Malaysia government have decided to include History subject as another compulsory subject to be passed in 
Sijil Pelajaran Malaysia (SPM) examination. This government's move is not to burden students, but to increase their knowledge of Malaysia history through their thinking skills. According to History Curriculum, Historical Thinking Skills (HTS) is one of the important thinking skills that need to be mastered by students in history learning process. Besides that, students are expected to learn actively through hands on activities like historical investigation, inquiry-based learning to ensure students have a deep understanding of what they had learnt at the same time arouse students' interest in learning history.

\section{Problems Statement}

Kaviza, Rahim and Bukhari research's in 2018 showed that the excessive use of History textbook left no rooms for both teachers and students to refer to other sources. One of the main reasons is because most of the history teacher are lack of ability to engage complex activities such as inquiry-based learning and sources-based learning in history classes. They did not receive any or sufficient training on pedagogical approaches that assist students in reading, understanding and constructing meaning from primary sources (Waring, 2017). When teachers themselves unprepared for implement these sources-based learning strategies in history classes, they will definitely not using digital primary sources in the classroom

Besides that, textbooks and teacher-centered pedagogy have been widely use in history classroom because teachers are lack of desire to engage digital primary sources and historical investigation in their history classes as they believe that their main responsibility is completing the syllabus within the given time frame, and ensure their students are well prepared for the SPM (Talin, 2016). Therefore, traditional teaching method has been used all the time since most of the teachers' intention is to prepare students for the exams. As a result, students lose their interest in learning history as they think that history is all about memorizing the facts.

However, textbook and teacher-centered pedagogy failed to stimulate students' thinking and research skill. Textbooks focus more on information recall, rather than interpretation, analysis or constructive processing. Therefore, the dependence on textbooks will create a less engaging classroom environment, and this causes students lack of understanding of how history is interpreted, lack of understanding about historical thinking process and lack of deep content knowledge of perception for historical events. Besides that, dependence of solely on textbooks negatively impact students' learning since textbooks may be objective, and it will limit students' ability to think differently according peoples or nations' perspectives (Harris, 2002).
Therefore, digital primary sources play a vital role in transforming history subject form a dull subject to an interesting and challenging subject. At the same time, through the use of digital primary sources in the classroom, students are changing their role from a passive knowledge recipient to an active historian or inquirer, which require students to carry out historical investigations that involved the process of evaluate and analyse digital primary sources, interpret the past events based on the evidences and draw they own conclusion. As a result, students will learn actively and gain a greater understanding of a past events. Therefore, digital primary sources are very potential history teaching aids that benefits students a lot.

\section{Digital Primary Sources}

Digital primary sources, refers to original manuscripts, government records, letters, photos, audios or film recordings that have been transferred into a digital format and made available via the internet. They requires both the use of technology and by nature are authentic and complex, which are a perfect enticement to encourage students to question, explore, analyze and interpret. Digital primary sources make learning process thoughtful and challenging, as students act as an historian, who master the historical thinking skill through the process of questioning, carrying a historical investigation and claiming a conclusion. According to Waring (2011), to encourage students think historically, student must be given opportunity to create their own authentic questions, utilize variety of sources, have the skill set to properly examine, read and determine the concept for original sources, be able to consider alternative perspectives, find sources to corroborate and question their hypothesis and construct their own narrative. Therefore, it is clear that primary sources and digital primary sources are vital for students to gain historical thinking skill through historical investigation and inquiry based learning. From this, students can have deeper understanding and intrinsically motivated when learning history.

\section{Research Methodology}

This research paper adopts a qualitative approach, using the method of literature review or library research to obtain information and reference sources related to the topic of the potentials of using digital primary sources in classroom. Through internet gadgets, the researcher gained access to various useful journals and articles by both local and international researchers.

\section{Data Analysis}


TABLE 1 The Potentials of Digital Primary Sources Based On Previous Researches

\begin{tabular}{|c|c|c|}
\hline \multicolumn{2}{|c|}{$\begin{array}{c}\text { Literature Review on The Potentials of Digital } \\
\text { Primary Sources }\end{array}$} & \multirow{2}{*}{$\begin{array}{l}\text { Findings } \\
\\
\text { - Deep } \\
\text { understand- } \\
\text { ing }\end{array}$} \\
\hline \multirow{3}{*}{$\begin{array}{l}\text { Fostering } \\
\text { Historical } \\
\text { Thinking } \\
\text { with } \\
\text { Digitized } \\
\text { Primary } \\
\text { Sources } \\
(2005)\end{array}$} & $\begin{array}{l}\text { - learn independently } \\
\text { - Working with digitized } \\
\text { primary sources gain } \\
\text { deeper understanding of } \\
\text { history } \\
\text { - learn the whole pictures of } \\
\text { history through materials } \\
\text { besides textbook } \\
\text { - Mastered a body of } \\
\text { knowledge in greater } \\
\text { detail than usual. }\end{array}$ & \\
\hline & $\begin{array}{l}\text { - Opportunity to think } \\
\text { themselves } \\
\text { - Students displayed good } \\
\text { historical thinking skill } \\
\text { - Providing few } \\
\text { opportunities to discuss or } \\
\text { debate idea } \\
\text { - Elicited a widely of } \\
\text { observations and } \\
\text { inferences } \\
\text { - Approach documents } \\
\text { actively, noting details, } \\
\text { drawing inferences and } \\
\text { using evidence } \\
\end{array}$ & $\begin{array}{l}\text { - Historical } \\
\text { investigation } \\
\text { - Historical } \\
\text { thinking skill }\end{array}$ \\
\hline & $\begin{array}{l}\text { - They have more work but } \\
\text { they like it more } \\
\text { - Connected them with } \\
\text { interesting assignments, } \\
\text { resources and activities }\end{array}$ & $\begin{array}{l}\text { - Arouse } \\
\text { interest }\end{array}$ \\
\hline \multirow{4}{*}{$\begin{array}{l}\text { Using Digital } \\
\text { Primary } \\
\text { Sources to } \\
\text { Teach } \\
\text { Historical } \\
\text { Perspective } \\
\text { to Pre service } \\
\text { Teachers } \\
\text { (2010) }\end{array}$} & $\begin{array}{l}\text { - Make history real } \\
\text { - Go into greater depth by } \\
\text { using primary sources help } \\
\text { students understand } \\
\text { history } \\
\end{array}$ & $\begin{array}{l}\text { - Deep } \\
\text { understand- } \\
\text { ing }\end{array}$ \\
\hline & $\begin{array}{l}\text { - Challenge students' } \\
\text { assumption through } \\
\text { historical inquiry } \\
\text { - Began asking more } \\
\text { question because want to } \\
\text { know more } \\
\end{array}$ & $\begin{array}{l}\text { - Inquiry based } \\
\text { learning }\end{array}$ \\
\hline & $\begin{array}{l}\text { - Help students to view a } \\
\text { historical event from multi } \\
\text { perspectives. }\end{array}$ & $\begin{array}{l}\text { - Multi } \\
\text { perspectives }\end{array}$ \\
\hline & $\begin{array}{l}\text { - Make history interesting } \\
\text { - Feel amazed and great to } \\
\text { experience the content at } \\
\text { first hand } \\
\end{array}$ & $\begin{array}{l}\text { Arouse } \\
\text { interest }\end{array}$ \\
\hline \multirow[t]{2}{*}{$\begin{array}{l}\text { Sumber } \\
\text { Sejarah } \\
\text { Digital } \\
\text { Terhadap } \\
\text { Amalan } \\
\text { Pemikiran } \\
\text { Sejarah } \\
(2014)\end{array}$} & $\begin{array}{l}\text { - Carry out historical } \\
\text { investigation } \\
\text { - Opportunity to engage } \\
\text { with history sources } \\
\text { without limitation } \\
\text { - Opportunity to collect } \\
\text { sources, interpret and draw } \\
\text { own conclusion based on } \\
\text { evidences }\end{array}$ & $\begin{array}{l}\text { - Historical } \\
\text { thinking skill } \\
\text { - Historical } \\
\text { investigation }\end{array}$ \\
\hline & $\begin{array}{l}\text { - Understand historical } \\
\text { concept } \\
\text { - Learn actively }\end{array}$ & $\begin{array}{l}\text { - Deep } \\
\text { understand- } \\
\text { ing }\end{array}$ \\
\hline Potensi di & - Students act as a historian & - Historical \\
\hline
\end{tabular}

\begin{tabular}{|c|c|c|}
\hline \multirow{2}{*}{$\begin{array}{c}\text { Luar } \\
\text { Tempurung: } \\
\text { Halatuju } \\
\text { Digitalisasi } \\
\text { Sejarah di } \\
\text { Malaysia } \\
\text { (2016) }\end{array}$} & $\begin{array}{l}\text { - Encourage students to } \\
\text { think historically } \\
\text { - Encourage students to } \\
\text { analyze and interpret the } \\
\text { sources }\end{array}$ & $\begin{array}{l}\text { thinking skill } \\
\text { - Historical } \\
\text { investigation }\end{array}$ \\
\hline & $\begin{array}{l}\text { - Make history alive } \\
\text { - Content more interesting } \\
\text { - Arouse students' interest } \\
\text { in learning history }\end{array}$ & $\begin{array}{l}\text { - } \text { Arouse } \\
\text { interest }\end{array}$ \\
\hline \multirow{3}{*}{$\begin{array}{c}\text { Intergrating } \\
\text { Primary } \\
\text { Sources, } \\
\text { Artifacts,and } \\
\text { Museum } \\
\text { Visits into } \\
\text { Primary } \\
\text { Years } \\
\text { Program } \\
\text { Inquiry } \\
\text { Curriculum } \\
\text { in an } \\
\text { International } \\
\text { Baccalaureate } \\
\text { Elementery } \\
\text { Setting } \\
\text { (2017) }\end{array}$} & $\begin{array}{l}\text { - Engaging historical } \\
\text { thinking } \\
\text { - Be given investigative task } \\
\text { - Involved brainstorming } \\
\text { and scaffolding }\end{array}$ & $\begin{array}{l}\text { - Historical } \\
\text { thinking skill } \\
\text { - Historical } \\
\text { investigation }\end{array}$ \\
\hline & $\begin{array}{l}\text { - Learn through questioning } \\
\text { - Engage students in } \\
\text { historical inquiries while } \\
\text { using primary sources } \\
\end{array}$ & $\begin{array}{l}\text { - Inquiry based } \\
\text { learning }\end{array}$ \\
\hline & $\begin{array}{l}\text { - Gain a better } \\
\text { understanding } \\
\text { - Additional sources support } \\
\text { students' understanding }\end{array}$ & $\begin{array}{l}\text { - Deep } \\
\text { understand- } \\
\text { ing }\end{array}$ \\
\hline \multirow{3}{*}{$\begin{array}{c}\text { Penggunaan } \\
\text { Sumber- } \\
\text { sumber } \\
\text { Sejarah } \\
\text { dalam Mata } \\
\text { Pelajaran } \\
\text { Sejarah : } \\
\text { Pilihan Murid } \\
\text { (2019) }\end{array}$} & $\begin{array}{l}\text { - Help students to connect } \\
\text { the sources with their real- } \\
\text { life experiences }\end{array}$ & $\begin{array}{l}\text { - Deep } \\
\text { understand- } \\
\text { ing } \\
\end{array}$ \\
\hline & $\begin{array}{l}\text { Encourage students learn } \\
\text { actively } \\
\text { - Help students to have a } \\
\text { high-level cognitive } \\
\text { thinking } \\
\end{array}$ & $\begin{array}{l}\text { - Historical } \\
\text { investigation } \\
\text { - Historical } \\
\text { thinking skill }\end{array}$ \\
\hline & $\begin{array}{l}\text { - Encourage inquiry-based } \\
\text { learning }\end{array}$ & $\begin{array}{l}\text { - Inquiry based } \\
\text { learning }\end{array}$ \\
\hline
\end{tabular}

\section{Discussion}

\subsection{Encourage Historical Inquiry}

Questioning is very important as it is the basis for the inquiry learning process. Digital primary sources such as photos, film recording and documents spark students' interest and provide an alternative way for students to increase substantive historical knowledge through questioning. Digital primary sources somehow served as a stimulus that prompt students' historical inquiry (Coppersmith \& Song, 2017). Student act passively when a traditional method is used to teach history, however, they act actively and in a sources-based learning class as watching a film recording able to motivate them to question more and know more (Waring \& Torez, 2010). Waring and Cheryl's research in 2012 showed that students will have a lot of questions to ask once they are given the opportunity to access digital primary sources, and their curiosity will lead them involve in the process of historical inquiry authentically. For example, when students are given chance to use digital primary 
sources, they will act like a detective, exploring and collecting numerous digital primary sources and offering their own interpretation of those sources. In this case, it is clear that historical inquiry occurs in learning process, where students will not be told by teacher what they need to know, but they are instructed by teacher about what knowledge is important to create in each topic. The more use of digital primary sources, the more development of inquiry-based habits of mind

\subsection{Foster Historical Thinking Skill through Historical Investigation}

The use of digital primary sources encourage student to act like a historian, they are given opportunity to think themselves when they are given investigative task (Yacob, Rus\& Zainol, 2016). For example, the topic 'The Independence of Malaysia' can be learnt through historical investigation where students need to make their effort to investigate it, through the accessibility of countless digital primary sources such as digital photos, films, letters, documents and audios. To complete the task given, students will approach documents actively. They need to scan and parse the digital primary sources. Another important reasoning skill that can be developed is sourcing, which require students to considerate who made those primary sources and their motives since the connection between primary sources' content and the creator is very strong. Students also need to observe the details, making inferences, citing evidence when making inferences and drawing conclusion (Tally \& Goldenberg, 2005). At last, they need to compare their conclusion with other's conclusion. This whole complex process requires students to display a good historical thinking skill. In this process, students identify the feeling of historical figures by contrasting them with their own experiences in life, they will feel the same way, and they will understand the behavior of past time actors by taking account of the approaches, intentions and beliefs, from here, students develop their empathy because they truly understand and the ideas and opinions in context. Therefore, digital primary sources are very potential in fostering students' historical thinking skill through historical investigation.

\subsection{To view Historical Event from Multi Perspectives}

For so long, History textbooks have become the only tool or reference for student to learn a historical event, which means textbook version is the only version students could access. As a result, students are frustrated and irritated with the way history has been presented to them all the time. Furthermore, a historical event should not be given a version only since it always had involved a lot of people from different races, background and parties with different beliefs, intentions and ideologies. Therefore, the use of primary sources is very significant to encourage students to see the events of the past in a multi perspective way. Digital primary sources served as a vehicle to challenge students' belief and assumption upon a historical event. The variety of digital primary sources from different collections allow students to have a variety of perspectives for one particular historical event. For example, the access of both Malaysia and British digital primary sources encourage students to see a historical events from two opposite perspectives, which are ruler's perspective and colony's perspective. In this case, the use of digital primary sources allow student to look at the sides that they may never considered through the textbooks (Waring \& Torrez, 2010). Digital primary sources allow student to think freely rather than being given the textbook author's perspectives, and this give opportunity to students to establish their own thinking based on the evidences. At the end, they will create their own interpretation and version of the events. Therefore, digital primary sources are important in helping students to view a historical events from in multi perspectives way.

\subsection{Gain Deeper and Greater Understanding}

The using of digital primary resources enable students to have a deeper and greater understanding on the past events (Kaviza, 2019). Digital primary sources encourage students probe deeply into the context of the historical time. The focus is not about what was happening, but what was going on within a timeline. Student will benefit from digital primary sources that showed specific human conditions, decision, emotions and actions rather than generic overview. It is because primary sources are not generic text written or created to offer summary explanation of other peoples' experiences, they are specific and rooted to the personal perspectives of human in history who created them. Therefore, the use of digital primary sources allow students to develop a deep understanding of the time period. They will connect the ideas and create a big idea based on what they have discover (Ramakrishnan, Esa \& Abdullah, 2014). For example, when students study about the topic of The Independency of Malaysia, they will be aware of peoples' action, emotion, characteristic and attitudes towards the nation's independency with more detail and specificity. They will also need to have a sense of continuity and change so that they can understand they changes of people towards the colony of British from 18th century to 20th century. Through this, student will have a deeper and greater understanding for this topic as digital primary sources have much more powerful impact on enhancing students' understanding. After all, students may draw their own conclusion about the historical event and realize how sources can be used to make an event of the past so clear. 


\subsection{Arouse Students' Interest}

The use of digital primary sources make students feel awesome because they can engage with adequate learning materials besides the History Textbook. Although the use of digital primary sources involved a lot of group works, investigative tasks and projects, however, students still enjoy and prefer this helpful learning process (Tally and Lauran, 2005). They feel amazed and touched when they are exposed to the digitized primary sources such as words, stories, videos and autobiography (Diekema, Leary, Haderlie \& Walters, 2011). They are motivated to work with the historical events as the digital primary sources' content make the historical events more real and alive (Yacob, 2016). Furthermore, through the using of digital primary sources as learning aids, students are given opportunity to learn in a group or through websites and webinar software. It is a student-centered pedagogy that encourage students to participate actively, support students to students interaction and teachers and students collaboration. Therefore, digital primary sources are very helpful to motivate and arouse students' interest in learning history since the learning process has become an enjoyable process

\section{Implication}

In some western countries, the accessibility of historical primary sources are greatly enhanced through technology because digitization and archiving of historical documents is expanding rapidly (Friedman, 2005). In those countries, digital primary resources are more searchable than nondigital sources and that makes their history learning more to hands on activities. Some schools and teachers have the same vision like western countries, they realized the vital of using digital primary sources in teaching and learning history process, however, the problem is, it is costly to create a digital primary resources website with rich sources (John, 2006). Therefore, it would be more rational if Malaysia's Ministry of Education able to prepare a digital resource centers as a platform for both primary, secondary students to access various digitized primary sources according to the syllabus. Each type of sources such as government documents, diaries, photos, audio and film recording that relevant to the topic of History subject should be gathered and categorized for students to access.

Digital primary sources on the web realize full potential only when they are found and used in a meaningful way. Therefore, Ministry of Education should provide history teachers with training and professional development activities to enable the use of primary source materials in the classroom and other education programs. Teachers who are lack of formal training in finding and using primary sources, unsophisticated computers and computer skills should be trained before they return to the classroom and integrate digital primary sources and instruct students to engage historical evaluation in history lesson with a meaningful way. This is very important because, without knowledge and skill of accessing and using, digital primary sources will be just a waste of potential and effort.

Previous research shows that pre-service teacher have awareness about the important of developing students' historical thinking skill but they are unaware of sources that can help them in developing historical thinking skills and historical investigation (Ozmen, 2015). Most of them neither received any training nor attend any educational activities related to historical thinking skill throughout their learning. This lack of knowledge and skills may signal that they need to increase the content of knowledge and skill (Cowgill II \& Waring, 2017) Therefore, historical investigation, conferences, field trips should be provided for all pre-service history teacher during their teacher history educational programs.

\section{Conclusion}

Digitized primary sources such as digitized pictures, photos, audio, films recording, and diaries help students to understand, analyze, interpret and evaluate those messages. It is very essential to develop students' historical thinking skill and historical inquiry. Through variety of digital primary sources, students will be able to make a clear links between what that see and what they interpret this to mean. It is very helpful to avoid false assumption besides encourage them to justify their interpretation. At the same time it break students' preconceptions that there is not only one true version of the past. When teachers' integrate digital primary sources into students' learning process, students are allowed to use digital primary sources as a starting point for selfdirected research. This may arouse students' interest in learning history as they can work together actively and create multimedia presentation, portfolio or creative writing based on their findings. As a result, students develop a deeper and greater understanding of a historical events. In conclusion, the power behind digital primary sources can help students learn more than history content and will have increased their motivation and greater skill to be a lifelong learner (Diekema, Leary, Haderlie \& Walters, 2011).

\section{References}

[1] Coppersmith, S. A., \& Song, K. H. (2017). Integrating Primary Sources, Artifacts, and Museum Visits into the Primary Years Programme Inquiry Curriculum in an International Baccalaureate 
Elementary Setting. Journal of Social Studies Education Research, 8(3), 24-49.

[2] Diekema, A. R., Leary, H., Haderlie, S., \& Walters, C. D. (2011). Teaching Use of Digital Primary Sources for K-12 Settings. D-Lib Magazine, $17(3 / 4)$.

[3] Friedman, A. (2005). Using Digital Primary Sources to Teach World History and World Geography: Practice, Promise and Provisos. 8(1)

[4] Harris, F. (2002). There Was a Great Collision in the stock market: Middle School Students, Online primary sources, and Historical Sense Making. School Library Media Research (5), 422-447

[5] John K. Lee. (2006). Social Studies and History Teachers' Uses of Non-Digital and Digital Historical Resources. 1(3): 291-311

[6] Kaviza, M. (2019) Penggunaan Sumber-sumber Sejarah dalam Mata Pelajaran Sejarah : Pilihan Murid . Jurnal Sultan Alauddin Sulaiman Shah. 6(1) 30-38

[7] Kaviza, M., Rahim, F. A., \& Bukhari, N. (2018). Tahap Kesediaan Guru-Guru Sejarah Dalam Melaksanakan Kaedah Pengajaran Dan Pembelajaran Berasaskan Sumber Sejarah: Satu Tinjauan Di Negeri Perlis. Juku: Jurnal Kurikulum \& Pengajaran Asia Pasifik, 6(2), 23-31.

[8] Ozmen, C. (2015). Social Studies Teacher Candidates Views on Historical Thinking Skills. Educational Research and Reviews, 10(14), 20312042.

[9] Ramakrishnan, R., Esa, N., \& Abdullah, S. H. (2014) Kesan Penggunaan Sumber Sejarah Digital Terhadap Kemahiran Pemikiran Sejarah. In: 23rd International Conference of Historians of Asia 2014 (IAHA2014), 23 - 27 August 2014, Alor Setar, Kedah, Malaysia.

[10] Talin, R. (2016) Why Historical Thinking Skills was not there? International Journal of Learning, Teaching and Educational Research. 15(3): 134142.

[11] Tally, B., Goldenberg, L.B. (2005). Fostering Historical Thinking with Digitized Primary Sources. Journal of Research on Technology in Education.

[12] Warring S.M. (2011). Preserving History: The Construction of History in the K-16 Classroom. Charlotte, NC: Information Age Publishing.

[13] Warring S.M., Cowgill II, D.A. (2017). Historical Thinking: An Evaluation of Student and Teacher Ability to Analyze Sources. Journal of Social Studies Education Research. 8(1) 115-145.

[14] Warring S.M., Torrez, C. (2010) Using Digital Primary Sources to teach historical perspectives to
Pre-service teachers. Contemporary Issues in Technology and Teacher Education. 10(3): 294-308

[15] Yacob, S., Rus, A. K. A. M., \& Zainol, R. (2016). Potensi di Luar Tempurung: Halatuju Digitalisasi Sejarah di Malaysia. Geografia-Malaysian Journal of Society and Space, 12(13). 